\title{
Resource Use Efficiency Analysis for Potato Production in Nepal
}

\author{
Mahesh Sapkota $^{1 @}$ and Mahima Bajracharya ${ }^{2}$ \\ sapkotamahes@gmail.com, iD http://orcid.org/0000-0003-4391-7065 \\ Plaza, Kathmandu, Nepal \\ Received 10 March 2017, Revised 2 Dec 2017, Accepted 25 Jan 2018, Published 28 \\ April 2018 \\ Scientific Editors: Hari Bahadur KC, Dinesh Thapa, Bal Kishna Joshi \\ Copyright $\odot 2018$ NARC. Permits unrestricted use, distribution and reproduction in \\ any medium provided the original work is properly cited.
}

${ }^{1}$ Ministry of Agriculture, Land Management and Cooperative, Department of Agriculture, Harihar bhawan, Nepal; @ :

${ }^{2}$ Ministry of Agriculture, Land Management and Cooperative, National Agricultural Research and Development Fund, Singhadurbar

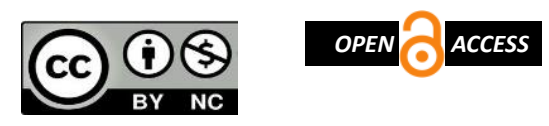

Licensed under the Creative Commons AttributionNonCommercial 4.0 International (CC BY-NC 4.0)

\begin{abstract}
Potato is one of the most important staple foods supporting food security and livelihood to millions of marginalized and poor farmers in Nepal. Generally the smallholders' farmers, especially those located in remote villages are inadequately informed about technical knowledge, inputs and efficient use of resources causing poor production and low productivity. Thus, the present survey aimed to examine the efficiency of resources used in potato production in Baglung District, one of the remote hilly place located in Central Himalaya. The total of 120 potato growing households was selected using simple random sampling technique from the two potato pocket in 2016. The regression coefficients of each inputs using Cobb-Douglas production function were estimated using Stata software. Our results showed that major inputs such as labor, bullock, Farm Yard Manure (FYM) and intercultural operations were overused and need to decrease in terms of cost by 109, 177, 51 and $185 \%$, respectively for its optimum allocation. Similarly, seed was found underused and need to increase its cost by $70 \%$ for optimum allocation. We concluded that inadequate training, exposure, knowledge gap and extension service to farmers in study sites were the reasons that farmers were using their resources inefficiently. It is recommended that the farmers involved in potato farming in the surveyed sites should be provided with additional proper technical knowledge for optimizing the use of resources which would help to increase the production and return from potato production.
\end{abstract}

Keywords: Efficiency, Inputs, Optimum, Potato, Resource

साराशं

नेपालको पहाडी तथा मध्य पहाडी भू-भागहरुमा आलु एक महत्वपूर्ण बालीको रुपमा रहेको छ। आलु उत्पादनमा प्रयोग हुने विभिन्न लागतहरु प्रभावकारी ढड़ले प्रयोग नहुँदा आलुको उत्पादन र आलु खेतीबाट हुने आम्दानी विशेष गरी दुर्गम जिल्लाहरुमा कमि रहेको पाईन्छ, । यसै विषयलाई मध्यनजर गर्दे बाग्लंग जिल्लामा आल खेती सम्बन्धी एक वैज्ञानिक अध्ययन गरिएको थियो। आल उत्पादन प्रक्यामा प्रयोग गरिने श्रोत साधनको प्रभावकारीता विश्लेषण गर्न यस अध्ययनको मुख्य उदेश्य रहेको छ। यस अध्ययनको लागि सन् २०१६ मा बाग्लुंग जिल्लाको दुई प्रमुख आलु उत्पादन क्षेत्रबाट सामान्य छनौट तरिकाबाट कुल १२० घरधुरी छानिएको थियो । इस्टाटा सफ्टवेयर प्रयोग गरि कब-डग्लस उत्पादन क्रियाबाट प्रत्येक श्रोतको रिग्रेसन कफिसिएन्ट भिकिएको थियो । जनश्रम, गोरुधन, मल र गोडमेल बढ़ी प्रयोग भैरहेको र बिउको प्रयोग कम भएको श्रोत प्रयोग क्षमताले देखाएको छ। यस अर्थमा जनश्रम, गोरुधन, मल र गोडमेलको लागत मूल्यमा कमश १०९, १७७, ५१ र १६५ प्रतिशतले कम गर्नुपर्ने र बिडको लागत मुल्यमा ७० प्रतिशतले वृद्धि गर्नुपर्ने यस अध्ययनले देखाएको छ। तसर्थ आलुबाट उचित आर्थिक फाईदा लिन उपलब्ध श्रोतहरुको सर्वोत्तम प्रयोग गरि उत्पादनको प्रभावकारिता बढाउनु पर्ने देखिन्छ,। किसान समक्ष आलु खेती प्रविधि सम्बन्धि उपयुक्त प्राविधिक ज्ञान र तालिम उपलब्ध भएमा यस क्षेत्रमा आलुको उत्पादन र आलुबाट आम्दानी बढाउन टेवा पुग्ने पनि यस अध्ययनले देखाएको छ।

\section{INTRODUCTION}

Potato is grown worldwide in more than 150 countries of the world as staple food including Nepal (Ezeta 2008). Out of total agricultural land, potato cultivation is known to occupy about $6.47 \%$ which is about 199,971 hectares (ha) and the total production reached about of 2,805,582 tons (t) with average productivity of $14.03 \mathrm{t} / \mathrm{ha}$ in 2015/16 in Nepal (MESD 2017). Potato is grown from an altitude of about 100 meter mean above sea level (masl) to 4000 masl in Nepal. Mostly the farming is subsistence type with small landholding of only 0.68 ha (CBS 2013). The cultivation of potato is popular among smallholder farmers due to its wider adaptability, high yield potential and demand. Thus becomes major sources of food, income and employment to many Nepali rural farmers. The share of potato to Gross Domestic Product (GDP) and Agriculture Gross Domestic Product (AGDP) were 2.17 and $6.57 \%$, respectively (ABPSD 2015).

In Baglung, a mid-hill district, potato is cultivated in 1,665 ha of land with total production of 19,758 $t$ and productivity of 11.8 t/ha (DADO 2015). The two area of Baglung district known as Bobang Village Development Committee (VDC) which is Dhorpatan Nagarpalika now and Tara VDC (now Tarakhola 
Gaunpalika) are the major pocket sites of potato. In Bobang, potatoes are grown as a mono-crop, which is found as a suitable place since viral degeneration generally occurs more slowly at higher altitudes and storage is much less of a challenge (Dhital 2000).

Since agriculture practices generally involve mostly marginalized and smallholder farmers in Nepal, especially in hills. Thus, it is likely that poor technical knowledge might be hindering the production and productivity due to poor understanding about the efficient resource use. Here, efficiency of resource use is defined as the ability to derive maximum output per unit of resource, which is the key to effectively address the challenges of achieving food security, while 'resource' is stock or supply of money, materials, staff, and other assets that can be drawn on by a person or organization in order to function effectively (Rahman and Lawal 2003). According to Heady and Egbert (1964) the resources are said to be efficiently used, if the last unit of each resources yield equal marginal productivity. Analysis of resource use efficiency helps to determine whether the resources are overused or optimally used or underused. Inefficient use of resources increases the cost of production, thus might resulting low return from potato production. The rapidly growing population resulting in speedy urabnisation where agricultural lands being converted into residential buildings (Ishtiaque et al 2017) creating huge demand of food. In respect to these relevant issues, only few studies have analyzed the efficiency of resources use in agriculture focusing on farmers' perception. Therefore, we aimed to elucidate the efficiency of resources use pattern among marginalized farmers in hilly region of Nepal involved in potato production. It is crucial to determine the level of production function as it helps and provides idea to manage the available resources efficiently to increase the production and maximize return using existing resources.

\section{METHODOLOGY}

\section{Sampling Techniques}

The present survey was conducted in Baglung district, representing a hilly landscape almost in the middle of Nepal in Central Himalayas, spreading from 83'E to 83'36"E and 28'15"N to 28'37"N. We selected two pocket sites of potato production namely Bobang and Tara Village Development Committee (VDCs) of Baglung District purposively (Figure 1). The potatoes produced in these locations are known for better taste, quality and organic product (DADO 2015). A total of 120 samples (potato growing households) were selected randomly or face-face interview method using semi structured questionnaire in the month April, 2016. The interview schedule was pretested among six farmers of Bhankunde VDC of Baglung. The necessary corrections and modifications were made in the questionnaire before its administration to actual respondents for the collection of primary data. Data regarding on socio-demographic and economic aspects as well as the amount of resources used in the production process were collected. Two focus group discussions were made to triangulate the data obtained during field survey. The data were coded and necessary cleaning and missing data techniques were employed during data entry to Statistical Packages of Social Sciences (SPSS) software. Descriptive analysis was done using SPSS and regression analysis using Cobb-Douglas production function in Stata software was used to determine resource use efficiency.

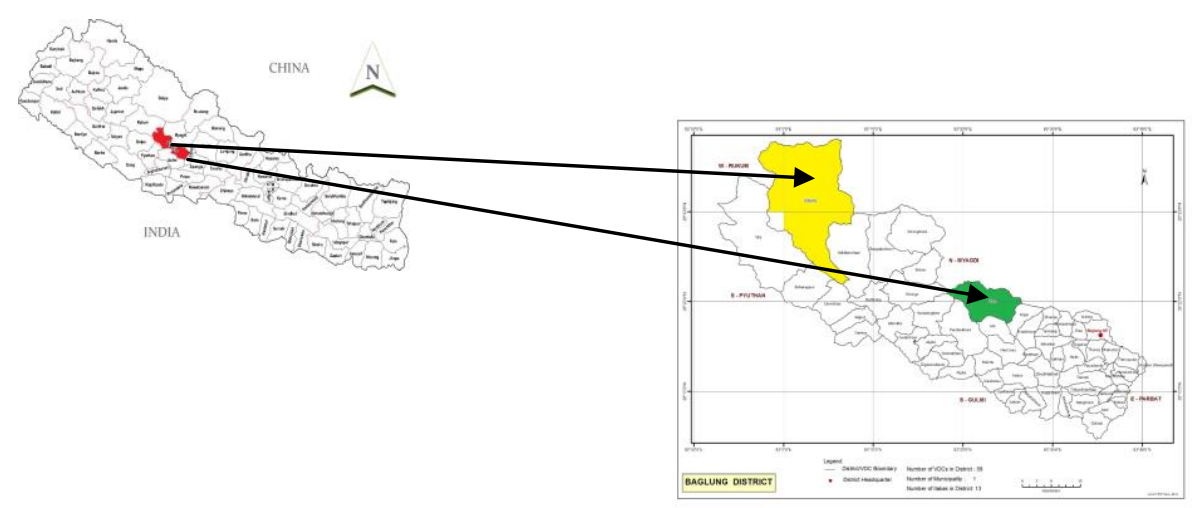

Figure 1. Map of Nepal and Baglung district showing the study sites. The shaded area represents the study sites

Estimation of Resource Use Efficiency

We used Cobb-Douglas production function to assess resource use efficiency following the methods mentioned by Rahman and Lawal (2003). 
$\mathrm{Y}=\mathrm{a} X_{1}^{b_{1}} X_{2}^{b_{2}} X_{3}^{b_{3}} X_{4}^{b_{4}} X_{5}^{b_{5}} e^{u}$

Where,

$\mathrm{Y}=$ Total return from potato production in Nepalese Rupees (NRs)

$\mathrm{X}_{1}=$ Total cost of seed used in potato production in NRs

$\mathrm{X}_{2}=$ Total cost of manure used in NRs

$\mathrm{X}_{3}=$ Total cost of labor used in NRs

$\mathrm{X}_{4}=$ Total cost of bullock used for tillage operations in NRs

$\mathrm{X}_{5}=$ Total cost of intercultural operations in potato field in NRs

$\mathrm{a}=$ Intercept

$\mathrm{e}^{\mathrm{u}}=$ Error term

$b_{1}, b_{2} \ldots . . b_{5}$ are the regression coefficients to be estimated. Both dependent and explanatory variables were transformed to natural logarithm. The above equation was transformed to linear form for ease in computation.

The level of resource use efficiency was calculated using following formula:

$\mathrm{r}=\frac{\mathrm{MVP}}{\mathrm{MFC}}$, Where,

$r=$ Efficiency ratio

MVP = Marginal Value Product; which is the value of incremental unit of output resulting from the additional unit of inputs.

MFC $=$ Marginal Factor Cost which is equal to one since both dependent and explanatory variables are converted to monetary value; and is defined as the increase in the cost of inputs due to purchase of additional unit of inputs.

Now, MVP $=\frac{b_{i} * \bar{Y}_{i}}{\bar{X}_{i}}$, Where,

$\mathrm{b}_{\mathrm{i}}=$ Estimated regression coefficient of input $\mathrm{X}_{\mathrm{i}}$

$\bar{Y}_{i}=$ Geometric mean value of output.

$\bar{X}_{i}=$ Geometric mean value of $\mathrm{i}^{\text {th }}$ resources used

Decision rule:

$\mathrm{r}=1$; Efficient use of resource

$\mathrm{r}>1$; Underused of the resource

$\mathrm{r}<1$; Overused of the resource

Finally, the relative percentage change in MVP was calculated using following way:

$\mathrm{D}=(1-\mathrm{MFC} / \mathrm{MVP}) \times 100$

Or, $\mathrm{D}=(1-1 / \mathrm{r}) \times 100$

where, $\mathrm{D}=$ absolute value of percentage change in MVP of each resource (Mijindadi1980).

For calculation of many parameters used in resource efficiency calculation values given in Appendix 1 were used.

\section{RESULTS}

Socio-economic and demographic characteristics

Descriptive analyses of various socio-economic, demographic and institutional variables are presented in Table 1. The average age of household head revealed that the farmers were acquired with enough skills and experience in the production process. The average size of household was higher as compared to national average of 4.88 (CBS 2012). The result on dependency ratio was close to the national average of 0.84 . The study sites were male dominated society with agriculture as their main occupation. Livestock is an integral part of Nepali farming and has an average ranking of 6-Livestock Standard Unit (LSU) in study sites (Table 1).

\section{Estimation of Resource Use Efficiency}

The major resources used in the process of potato production were seed, human labor, bulls, farm yard manure (FYM) and operations of intercultural activities such as weeding and earthing up, etc. (Appendix 1). In the study site, male were involved more in land preparation and female in sowing, weeding and harvesting. CobbDouglas production function was used to analyze the efficiency of resources used in the production process where total return from potato was taken as dependent variable and other resources involved in production process as explanatory variables (Table 2 ). 
Table 1. Description of socio-economic, demographic and institutional variables

\begin{tabular}{lclr}
\hline Variables & Mean & \multicolumn{1}{c}{ Variables } & Frequency \\
\hline Age of respondent (year) & $42.05 \pm 12.67$ & Gender of HH (Male = 1) & $108(90.0)$ \\
\hline Age of household head (year) & $47.91 \pm 13.27$ & Ethnicity (Janjati =1) & $62(51.7)$ \\
\hline Schooling of household head (year) & $3.06 \pm 3.33$ & Occupation (Agriculture =1) & $103(85.8)$ \\
\hline Household size & $6.20 \pm 2.41$ & Family type (Nuclear =1) & $76(63.3)$ \\
\hline$\quad$ Male members in household & $3.26 \pm 1.53$ & Memberships in social groups (Yes = 1) & $24(20)$ \\
\hline Female members in household & $2.94 \pm 1.44$ & Participation in training (Yes = 1) & $10(8.3)$ \\
\hline Economically active members & $3.63 \pm 1.81$ & & \\
\hline Dependency ratio & $0.88 \pm 0.71$ & & \\
\hline Educated members in household & $4.81 \pm 2.42$ & & \\
\hline Total landholding (ha) & $0.89 \pm 0.83$ & & \\
\hline Cultivable land (ha) & $0.36 \pm 0.29$ & & \\
\hline Land area under potato cultivation (ha) & $0.19 \pm 0.13$ & & \\
\hline Livestock holding (LSU) & 5.61 & & \\
\hline Note: Figures in parentheses indicate percentage and value after " $\pm "$ indicate standard deviation.
\end{tabular}

Table 2. Estimation of resource use efficiency using Cobb-Douglas production function

\begin{tabular}{lcccccr}
\hline Variables & Coefficient & MVP & MFC & r & D-value & Efficiency \\
\hline Ln_Seed & 0.639 & 3.348 & 1 & 3.348 & 70.13 & Underused \\
\hline Ln_Human labor & 0.075 & 0.478 & 1 & 0.478 & 108.89 & Overused \\
\hline Ln_Bullock for tillage & -0.015 & -1.301 & 1 & -1.301 & 176.84 & Overused \\
\hline Ln_FYM & 0.190 & 0.661 & 1 & 0.661 & 51.26 & Overused \\
\hline Ln_Intercultural operations & -0.047 & -1.180 & 1 & -1.180 & 184.73 & Overused \\
\hline
\end{tabular}

\section{DISCUSSION}

The present resource use efficiency analysis showed that major inputs in potato cultivation such as labor, bullock, FYM and intercultural operations were overused and need to decrease their cost for its optimum allocation (Table 2). It was also revealed that potato seed was underused, thus need to increase its cost at least by $70 \%$ for optimum allocation. This might be due to lack of training exposures to farmers and insufficient extension service to farmers in study site. We argue the reasons behind such unawareness to farmers might be due to poor exposure and training to involved farmers in seed production activities. So, it would be highly recommendable to enrich the farmers with appropriate technical information, exchange of ideas and exposure, so they could be able to obtain optimum price for their resources for increasing production and return from potato.

The ratio of MVP (Marginal Value Product) to MFC (Marginal Factor Cost) was lesser than the unity for all resources used in potato production except seed cost which was greater than unity (Table 2). This revealed that the resources were not used to optimum economic advantage. There is need for adjustment in the marginal value product of all the resources to ensure optimal use. Participation in social groups might help to exchange knowledge and experiences and increase bargaining power of farmers to purchase inputs and sell their products. Since the participation in social groups and trainings was found minimal which revealed poor extension service in study sites. The land separated for potato cultivation was very less as compared to total land owned by household. It is due to complex topography and lack of technical knowledge among farmers.

Potato production being labor intensive activity, family labor was a readily available pool of labor to draw from whenever requires thus surplus family labor might have led to the overuse of labor. Agricultural mechanization or use of machinery equipment was negligible in the study sites. Use of local molded board plough was found which also requires labor force. Thus, labor force was one of the major inputs in the potato production in the study site. This finding was in line with Danso-Abbeam et al (2015) mentioned in Tolno et al (2016).

Sapkota (2016) also found the cost on FYM, human labor and tillage operations as overused resources in maize seed production in Palpa district of Nepal and need to decrease the cost by about 665, 68 and $456 \%$, respectively, for its optimum allocation. Also there was lack of technical knowledge about potato farming and this situation might have led to overuse of these resources. In case of farmyard manure, farmers used all the year round deposited manures in the field and apply it in a traditional way without any care of recommendation which increases the cost of manures and lead to its inefficient use. Farmers deposit the manures in bulk in field

${ }^{1}$ LSU $=$ Livestock Standard Unit

LSU $=1$ cow/bull +1.5 buffalo +0.6 swine/ pig +0.4 goat/sheep +0.02 poultry (Adhikari 2000 cited in Ghimire 2012) 
under open sky which has caused in the loss of nutrients from it. Thus, low production although heavy use of farm yard manures in potato production. So, the cost of farm yard manure is found as overused in the study sites. The finding was in line with Tripathi et al (2005), showed that the efficiency ratio (MVP:MFC) of the input manure and fertilizers was less than one which states that this input was overused in the potato contract farming at Haryana state of India. Sujan et al (2017) showed manure as over-utilized resource and contrast with the result of the inputs human labor and land preparation which was under-utilized and seed as over-utilized resource in a study conducted at Munshiganj District of Bangladesh. Similarly, more cost was incurred mainly in bullock use for tillage and in intercultural operations for weeding and earthing up. Likewise using ware potato as seed tubers had resulted in underused resources which are mainly concerned in the quality of seed. This is because of difficult geographical locations the farmers probably were unaware about size and quality of tubers to be used as seed tubers.

Shrestha et al (2016) explained that production efficiency of vegetable farming could be increased with a greater access to improved seed, agricultural credit, training and extension services in eastern high hills of Nepal. Mahatha (2012) stated seed, irrigation, plant protection chemicals, potash and Di-ammonium phosphate (DAP) were underused resources. Thus, farmers could improve economic efficiency and productivity if they use more of these resources. Ghimire and Dhakal (2014) revealed the expenditure on chemical inputs in tomato production and human labor in cauliflower and cabbage production were overused after sustainable soil management program in Dhading District, Nepal. The resources such as seeds and irrigations were found overused whereas fertilizers, human labors and agrochemicals were found underused in the production process of Sorghum which appealed the optimum allocation of resources to maximize revenue at Andhra Pradesh, India (Chapke et al 2011). Sharma (2010) stated that land, human labor, variable and fixed expenses were overused in the production of cucumber in Nawalparasi District of Nepal. In contrast with these results, Ahmed et al (2015) found all the resources in the production process as underused resources in their study.

\section{CONCLUSION}

Potato is one of the most important potential crops to ensure nutritional value, food security and reduce poverty in the hilly regions of Nepal. The majority of the farmers are devoid of better extension services and lack of trainings for human capacity building in the study sites. Efficient use of resources is of much concern from economic point of view to increase the production level and maximize return. The resources such as cost on human labor, bullock for tillage, FYM and intercultural operations used in the production process were overused whose cost need to be decreased for its optimum allocation whereas cost on seed were underused and need to increase its cost for optimum allocation of resources. This appeals the need of proper technical knowledge among the farmers to use the available existing resources efficiently. This study concludes that the resources should be used wisely to maximize return. Government and other concerned stakeholders should give priority to provide efficient technical knowledge about good agricultural practice.

\section{ACKNOWLEDGEMENT}

We would like to provide our cordial thanks to National Agricultural Research and Development Fund, Singhadurbar Plaza, Kathmandu, Nepal for financial support to accomplish this study. We would like to acknowledge Agriculture and Forestry University, Chitwan, Nepal, mentors, DADO Baglung, respondents for their active and energetic participation for successful completion of this study.

\section{REFERENCES}

ABPSD. 2015. Statistical information on Nepalese agriculture 2014/15. Agri-Business Promotion and Statistics Division, Ministry of Agricultural Development, Government of Nepal, Kathmandu, Nepal.

Adhikari 2000. Cited in Ghimire B. 2012. Assessment of socio-economic impact of sustainable soil management practices on vegetables in Nalang and Salang VDCs of Dhading district. Master thesis submitted to Institute of Agriculture and Animal Science for the partial fulfillment of the requirements for the degree of Master of Science in Agriculture (AgriEconomics), Rampur, Chitwan, Tribhuvan University, Nepal.

Ahmed MT, SC Nath, MA Sorwar and MH Rashid. 2015. Cost-effectiveness and resource use efficiency of sweet potato in Bangladesh. Journal of Agricultural Economics and Rural Development, 2(2): 26-31.

AICC. 2015. Krishi Diary 2072. Agriculture, Information and Communication Center, Government of Nepal, Ministry of Agricultural Development, Department of Agriculture, Hariharbhawan, Lalitpur.

CBS 2012. National population and housing census 2011 (national report). Central Bureau of Statistics, Government of Nepal, National Planning Commission Secretariat, Kathmandu, Nepal.

CBS. 2013. National sample census of agriculture Nepal 2011/12 (national report). Central Bureau of Statistics, Government of Nepal, National Planning Commission Secretariat, Kathmandu, Nepal.

Chapke RR, B Mondal and JS Mishra. 2011. Resource-use efficiency of sorghum (Sorghum bicolor) production in rice (Oryza sativa)-fallows in Andhra Pradesh, India. Journal of Human Ecology, 34(2):87-90.

DADO. 2015. Annual agriculture development program and statistics book FY 2071/72. Government of Nepal, Ministry of Agricultural Development, District Agriculture Development Office, Baglung. 
Danso-Abbeam and Bawa 2015. cited in Tolno E, H Kobayashi, M Ichizen, M Esham, BS Balde. 2016. Potato production and supply by smallholder farmers in Guinea: an economic analysis. Asian Journal of Agricultural Extension Economic Society, 8(3):1-16.

Dhital BK. 2000. Diffused light storage of seed potatoes in the hills of Nepal in relation to seed tuber physiology, production, environment and socio-economics, Doctoral dissertation submitted to University of Newcastle upon Tyne.

Ezeta FN. 2008. An overview of potato production in Asia and the Pacific region: Markets, development and constraints. RAP Publication (FAO).

Ghimire B and SC Dhakal. 2014. Production Economics of Sustainable Soil Management based Cauliflower (Brassica eoleracea. L. var. botrytis) in Dhading district of Nepal. American Journal of Agriculture and Forestry, 2(4):199-205.

Heady EO and AC Egbert. 1964. Regional programming of efficient agricultural production patterns. Econometrica: Journal of the Econometric Society, 374-386.

Ishtiaque A., M Shrestha and N Chhetri. 2017. Rapid Urban Growth in the Kathmandu Valley, Nepal: Monitoring Land Use Land Cover Dynamics of a Himalayan City with Landsat Imageries. Environments, 4(4), 72.

MahathaRK. 2012. Economics of production and marketing of Potato in Saptari district of Nepal. Master thesis submitted to Institute of Agriculture and Animal Science, Tribhuvan University, Chitwan, Nepal.

MESD. 2017. Statistical information on Nepalese agriculture 2072/73 (2015/16). Monitoring, evaluation and statistics division, Government of Nepal, Ministry of Agricultural Development, Agri-Statistics section, Singhadurbar, Kathmandu, Nepal.

Mijindadi NB. 1980. Production Efficiency on Farms in Northern Nigeria. Doctoral dissertation submitted to Cornell University, USA.

Rahman SA and AB Lawal. 2003. Economic analysis of maize based cropping systems in Giwi local Government area of Kaduna state, Nigeria. An international Journal of Agriculture. Science, Environment and Technology, 3(2):139-148.

Sapkota M. 2016. Economic analysis of maize seed production in Palpa district of Nepal: Prospects of improving technical efficiency. A master thesis submitted to Agriculture and Forestry University in partial fulfillment of the requirements for the degree of Master of Science in Agriculture (Agricultural Economics), Rampur, Chitwan.

Sharma BP. 2010. Production and marketing of cucumber (Cucumis sativus L.) in Nawalparasi, Nepal: An Economic Analysis. Master thesis submitted to Institute of Agriculture and Animal Science, Tribhuvan University, Rampur, Chitwan, Nepal.

Shrestha RB, WC Huang, S Gautam, and TG Johnson. 2016. Efficiency of small scale vegetable farms: policy implications for the rural poverty reduction in Nepal. Agricultural Economics, 62(4):181-195.

Sujan, HK, F Islam, MH Kazal and RK Mondal. 2017. Profitability and resource use efficiency of potato cultivation in Munshiganj district of Bangladesh, SAARC journal of agriculture, 15(2):193-206.

Thiele G, K Theisen, M Bonierbale and T Walker. 2010. Targeting the poor and hungry with potato science. Potato J, 37(34): $75-86$.

Tripathi RS, R Singh and S Singh. 2005. Contract farming in potato production: an alternative for managing risk and uncertainty. Agricultural Economics Research Review, 18(2):47-60.

Appendix 1. Total cost and income from potato cultivation in study sites

\begin{tabular}{lcr}
\hline Parameters & Cost (NRs./ha) & Share to total cost (\%) \\
\hline Seed & $46771 \pm 11049$ & 23.72 \\
\hline Human labor & $40455 \pm 17975$ & 20.52 \\
\hline Bullock for tillage & $4607 \pm 2258$ & 2.34 \\
\hline FYM & $89372 \pm 69621$ & 45.32 \\
\hline Intercultural operations & $10124 \pm 37923$ & 5.13 \\
\hline Other cost & $5857 \pm 6559$ & 2.97 \\
\hline Total cost & $197186 \pm 76225$ & \\
\hline Total income from potato production & $268047 \pm 136142$ & \\
\hline
\end{tabular}

Note: Figures after " \pm " indicate standard deviation. 